\title{
Comparative economic analysis of superintensive and intensive apple orchards
}

\author{
Szabó, V. \\ Bold-Agro Kft., General Direktor, H-4130 Derecske Köztársaság u. 114. email: szabo.viktor@boldagro.hu
}

\begin{abstract}
Summary: The objective of thsi study was to compare economic aspects of superintensive and intensive apple production. According to our results, conclusions and recommendations regarding the establishment of superintensive orchards are the followings: A yield of 60 tons per hectare in the average of the mature years provide a quite late payback, in this way yield losses should be avoided in the plantation of such a huge capital requirement. When yield losses happen, which cannot be avoided or may be avoided only in a limited way, up to 65 to 70 tons per hectare yield should be reached even in good years, in order to yield the average 60 tons per hectare in the long run. In this case yield losses from production technological mistakes must not be arisen. Inputs and professional expertise should be used in a maximum way in order to reach yields ensuring profitable production. Investment subsidies may ensure safer return. The return of a superintensive orchard from totally own sources may be risky under the domestic marketing conditions and selling prices, it is strongly uncertain.
\end{abstract}

Keywords: economic analyses, surepintensive, intensive, apple

\section{Introduction}

Greater number of superintensive apple orchards with Knipp trees and hail netting was established even in Hungary during the past years, which have already been determinant in Western-Europe for one to one and a half decades. The question arises, however, that whether these investments of a great capital requirement are able to ensure appropriate profitability and return under the domestic marketing and economic conditions. In our present analysis, this issue will be focused on in a way that the farm business conditions of superintensive orchards will be detailed by its comparison to that of intensive orchards.

Our objective in this study is to determine that what cost and profit relations are realized during the production and under what conditions an up-to-date superintensive apple orchard cultivated in an excellent way and on a high technological standard may be profitable. The calculation focuses on investment analysis on return regarding the whole lifetime of the orchard.

Fruit production has an outstanding role in the Hungarian agriculture, which is proved by the fact that it ties down a significant number of labour and assets in billion HUF, and it contributes to the gross production value of crop production by 8 to $10 \%$ (Z. Kiss, 2003). Fruit production has a relevant significance in improving living standard of rural population in lagged behind regions where the conditions of production site is weaker (Papp, 1999). Similarly to other branches of the national economy, our apple production has also been in a deep crisis for a long time. This is well indicated by the continuous, unstoppable yield decrease since the last decade in comparison with 1970'ies and 1980'ies, when the annual yield reached the 1 million tons. The produced yield of the Hungarian apple reached 450 to 500 thousand tons during the past years, though unfortunately there were years when it did not reach even the 400 thousand tons. In 1995, it hardly exceeded the 300 thousand tons (Gonda, 2000).

Based on Apáti (2009)'s research, per hectare net profit of 500 thousand HUF may be realized in intensive apple orchards considering 1500 thousand HUF production cost and 2000 thousand HUF production value. Even Apáti (2012) draws the attention to farm business characteristics of more intensive and more extensive orchards on which basis the intensive orchards are able to reach higher per hectare profit, while more extensive orchards are better in profit to cost ratio and return on capital, at the same time per hectare profit is lower in more extensive orchards, but there is not any significant difference between the two types of orchards relating to the payment period (DPP).

\section{Materials and methods}

In our present study the cost and profit relations of intensive and superintensive apple orchards cultivated on a high standard and being in good conditions are considered for the calculations of investment analysis on return. The definitions characterizing intensity are very relative and their contents are not clear in every case. In this way it is important to highlight that orchards are investigated having the parameters in Table 1 . 
Table 1: Parameters of the Characterized Superintensive and Intensive Apple Orchards

\begin{tabular}{|c|c|c|}
\hline Denomination & „Superintensive” & „Intensive” \\
\hline Rootstock & M9 & M9, maybe M26 \\
\hline Spacing & $3,25 \times 1,0 \mathrm{~m}$ & $4,0 \times 1,0 \mathrm{~m}$ \\
\hline Number of trees & 3077 trees/ha & 2500 trees/ha \\
\hline Planting material & Knipp tree & Sapling \\
\hline Crown form & \begin{tabular}{|l|}
$\begin{array}{l}\text { Slender spindle/super } \\
\text { spindle }\end{array}$ \\
\end{tabular} & $\begin{array}{l}\begin{array}{l}\text { Slender spindle/super } \\
\text { spindle }\end{array} \\
\end{array}$ \\
\hline Support system & $\begin{array}{l}\text { Support system with } \\
\text { concrete column and } \\
\text { wires suitable for } \\
\text { holding hail netting }\end{array}$ & $\begin{array}{l}\text { With support columns } \\
\text { and wires }\end{array}$ \\
\hline Irrigation & Drip irrigation & Drip irrigation \\
\hline Hail netting & $\begin{array}{l}\text { With concrete columns } \\
\text { and black netting of } 4.0 \\
\text { meters height }\end{array}$ & None \\
\hline Reachable yield* & $60 \mathrm{t} / \mathrm{ha}$ & $40 \mathrm{t} / \mathrm{ha}$ \\
\hline \begin{tabular}{|l|} 
Ratio of apple \\
for consumption \\
purposes
\end{tabular} & $95 \%$ & $85 \%$ \\
\hline Sold product & \multicolumn{2}{|c|}{$\begin{array}{l}\text { Apple harvested into a tank, preselected by hand } \\
\text { during picking, sold immediately after harvesting, } \\
\text { ripeness, colour and size are the expected features } \\
\text { from the variety. Storage, selection, package and } \\
\text { transportation do not occur, thus neither their costs } \\
\text { arise. The apple juice transported in bulk. }\end{array}$} \\
\hline
\end{tabular}

Source: own edit. Note: * It is the yield level which can be reached in the average of many years.

The examined orchards may be characterized by much higher yields than the national average, good product quality (size, ripeness), high inputs, production technology of good standard and strict technological discipline. These parameters illustrate not the Hungarian average but the best orchards (belonging to the upper third). The prices and prime cost of the used inputs (materials, labour, mechanical work) reflect the price standards of the years 2012-2013. The prices of materials were considered without VAT, the wages were calculated altogether with benefits. Hourly wages were counted on the basis of 700 HUF to every used labour hour. Selling prices are represented by a longer-term average (3 to 5 years). Data gathering forming the basis of the analysis happened in production enterprises.

The utilized analysing methods are cost-benefit analysis and investment analysis on return. In the latter case the dynamic methods were chosen as they give a more valid and precise results from the professional aspects. They differ from static methods in the fact that they count with the time value of money (Illés, 2002). There are several indicators for dynamic investment analysis, from which NPV (Net Present Value), DPP (Discounted Payback Period), IRR (Internal Rate of Return, return on capital) are calculated (Brealey, 2006). The return on capital of alternative investment is reflected by the calculative interest rate, which value is $7 \%$, being the interest need of the investment capital. The effects of investment subsidies of 40 to $60 \%$ are not taken into consideration, the calculations refer to orchard establishment from $100 \%$ own sources. Because of similar reasons SAPS and subsidies for agrarian and environmental farming and structural changing were not considered either.

\section{Results and discussion}

\section{Investment Costs}

The establishment of superintensive apple orchards requires twice as much capital as that of intensive orchards (Table 2). The major reasons of higher establishment costs may be the followings:

- A special attention must be paid to straightening the site and to melioration in orchards with hail netting, as water spots on the soil dry up slower, and may cause continuous problems in the movement of the machinery and vaporous and stifling microclimate.

- Concrete columns of 4.5 meters long capable of holding the hail netting and other heavy loads, the netting itself, other equipments of the hail netting system (transversal stay-wires, stronger anchors, wire-ropes, clips, etc.) require near 3.0 million HUF extra costs per hectare compared to a normal supporting system.

- The price of the Knipp trees is 4.0 to $5.0 €$ per tree (in average it is $4.5 € /$ tree), which is a purchase cost of 4.0 to 4.2 million HUF per hectare regarding 3077 trees. In case of 2500 saplings the same is at least 1.5 to 1.8 million HUF (600 to $700 \mathrm{HUF} /$ tree). Thus the price of the planting material shows a difference of approximately 2.5 million HUF. There is not any significant difference in other costs of planting.

- Establishing the irrigation system and the cost of other work reflects smaller differences, but significant extra costs do not occur.

Table 2: Investment Cost of the Characterized Apple Orchards (thousand HUF/ha)

\begin{tabular}{|l|c|c|}
\hline \multicolumn{1}{|c|}{ Denomination } & $\begin{array}{c}\text { "Superinten- } \\
\text { sive” }\end{array}$ & "Intensive" \\
\hline Site and soil preparation & 800 & 475 \\
\hline $\begin{array}{l}\text { Establishment of support system/hail } \\
\text { netting }\end{array}$ & 3800 & 1070 \\
\hline Graft and planting & 4300 & 2075 \\
\hline Establishment of irrigation & 800 & 775 \\
\hline Other costs & 250 & 250 \\
\hline Total plantation cost & 9950 & 4645 \\
\hline $\begin{array}{l}\text { Cultivating cost in the period of } \\
\text { mature state * }\end{array}$ & 2325 & 1190 \\
\hline Total investment cost & 12275 & 5835 \\
\hline Revenue in the period of mature state & 3455 & 1280 \\
\hline Clear investment cost & 8820 & 4555 \\
\hline Annual depreciation in mature state & 735 & 380 \\
\hline
\end{tabular}

Source: own calculation. Note: * The treatment lasts for 3 years. 
Besides the 100 to $120 \%$ higher establishment cost of superintensive orchards the costs of the first three growth years show twice as much difference as in case of intensive orchards. The reason is that in an orchard planted with saplings there is not any significant yield during the first two years, and even in the third year it yields only 15 to 20 tons per hectare. Thus the utilized technology is close to the productive years already in the second year (although due to the much lower yields, material and labour inputs are smaller), from the third year, however, the size of the inputs reaches the costs of the whole mature years. At the same time, it is true that using Knipp trees by which a total yield of 60 tones per hectare may be reached in the mature state, revenue of 3.5 million HUF may be realized even in the period of the investment. The revenue of mature state of orchards planted with saplings is only one third of this value.

As a consequence of the above mentioned, at the end of the mature state a clear investment cost of 9.0 million HUF occur in a superintensive orchard, while it is 4.5 million HUF in an intensive one. When these costs are depreciated equally to 12 years of the mature state, the annual depreciation cost in the mature years in superintensive orchards is twice as much higher than that of intensive orchards.

\section{The Result of Cultivation in the Mature State}

Summing up the revenue and cost data the major consequences relating to profit and profitability are the followings (Table 3):

- The per hectare profit before taxes (contribution, net profit) is 1.5 to 2.0 times higher in superintensive orchards.

- The cash flow reflects a similar condition as regarding a twice as much starting capital investment (establishment, investment cost) near twice as much clear profit may be reached in the mature state.

- Taking such yield and quality parameters into consideration the profit to cost ratio is more favourable in superintensive orchards. However, due to the much higher production costs, the profitability of superintensive orchards is more sensitive to yield losses, thus if frost damages or other yield losses caused by technological mistakes often happen, profit to cost ratio will be lower than in intensive orchards, still in case of higher profit.

It may be concluded on the basis of the above mentioned that much higher profit may be reached potentially in superintensive orchards in the mature years, but its price is the fact that twice as much capital should be available at the beginning.
Table 3: Profit and Profitability in Apple Orchards Cultivated on a High Standard in a Year without Extremities

\begin{tabular}{|l|l|c|c|}
\hline \multicolumn{1}{|c|}{ Denomination } & \multicolumn{1}{c|}{ Unit } & $\begin{array}{c}\text { Super- } \\
\text { intensive }\end{array}$ & Intensive \\
\hline REVENUE & thousand HUF/ha & $\mathbf{3 4 7 1}$ & $\mathbf{2 1 4 2}$ \\
\hline Direct production cost & thousand HUF/ha & 2260 & 1442 \\
\hline CONTRIBUTION & thousand HUF/ha & $\mathbf{1 2 1 1}$ & $\mathbf{7 0 0}$ \\
\hline Overhead cost & thousand HUF/ha & 200 & 200 \\
\hline Total production cost & thousand HUF/ha & 2460 & 1642 \\
\hline NET PROFIT & thousand HUF/ha & $\mathbf{1 0 1 1}$ & $\mathbf{5 0 0}$ \\
\hline Profit to cost ratio & $\%$ & 41 & 31 \\
\hline Cash flow & thousand HUF/ha & 1746 & 880 \\
\hline
\end{tabular}

Source: own calculation. Note: The calculation refers to immediately selling after harvesting without post-harvest

\section{Returning of the Production during the Whole Lifetime of the Orchard}

In the next part using the cost and profit relations illustrated in Table 3 projected to the whole lifetime of the orchard, the result of the dynamic investment analysis will be detailed. Figure 1 illustrates the net present values (NPV) of profits for both types of orchards, and Table 4 summarizes the major investment indicators.

Figure 1: The Tendency of NPV during the Lifetime of the Orchard

Years
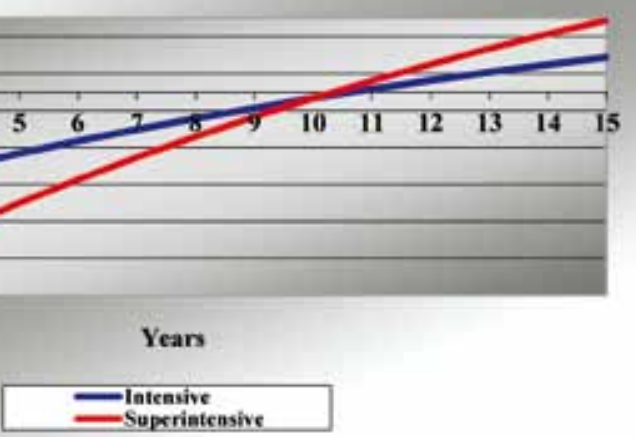

Source: own calculation

Table 4: Investment Indicators Relating to the Examined Orchards

\begin{tabular}{|l|c|c|c|}
\hline \multicolumn{1}{|c|}{ Denomination } & Unit & Superintensive & Intensive \\
\hline $\begin{array}{l}\text { Net present value of } \\
\text { profit (NPV) }\end{array}$ & $\begin{array}{c}\text { thousand } \\
\text { HUF/ha }\end{array}$ & 3888 & 1885 \\
\hline $\begin{array}{l}\text { Profit to capital ratio } \\
\text { (IRR)* }\end{array}$ & $\%$ & 10.4 & 10.3 \\
\hline $\begin{array}{l}\text { Payback Period } \\
\text { (DPP)** }\end{array}$ & year & 11. & 11. \\
\hline
\end{tabular}

Source: own calculation

The cumulated profit of superintensive orchard after the twice as much investment cost increases much more precipitously thank to the twice as much cash flow profits. At the end of the lifetime of the orchard, this value will be twice as much as that of intensive orchards. The returning happens almost at the same time ( $11^{\text {th }}$ year), as the much higher annual profits can compensate the huge capital requirement at the beginning (Figure 1 and Table 4). The higher cumulated profit 
(NPV) during the lifetime does not go with higher profit to capital ratio (IRR), it is important, however, that the profit to capital ratio of superintensive orchards is very sensitive to yield losses because of the huge capital requirement at the beginning, thus in case of frequent yield losses the profit to capital ratio of superintensive orchards will be much lower than that of intensive ones.

The consideration of superintensive orchards in WesternEurope is much more favourable than in Hungary, which has two basic reasons. At one hand, the land is much more expensive (the price of one hectare land ranges from 5 to 30 million HUF, or the land structure is so fixed that one cannot purchase land), thus it has a great significance that because of the huge fixed capital in the land as well as due to the fact that the size of the plantation cannot be increased, the biggest profit is realized from a single unit land. On the other hand, the quality is paid by much more differentiated, "the better than good and more homogenous" color and fruit size have much greater significance, which can be reached in superintensive orchards with a greater probability as well. The significance of the above mentioned returning parameters, mainly the much higher per hectare profit, of superintensive orchards, will be higher in Hungary, if land prices rise radically (or if there is no more land available) and if quality is paid by much more strictly, objectively and differentiated, which means that quality has a much higher "price". the payback period. In such a case the payback period of the orchard is in the $8^{\text {th }}$ year regarding yields of 50 tons per hectare, while considering 60 ton-per-hectare yield, it happens in the $7^{\text {th }}$ year.

\section{Conclusions and recommendations}

Asasummary, the majorconclusions andrecommendations regarding the establishment of superintensive orchards are the followings:

A yield of 60 tons per hectare in the average of the mature years provide a quite late payback, in this way yield losses should be avoided in the plantation of such a huge capital requirement. When yield losses happen, which cannot be avoided or may be avoided only in a limited way, up to 65 to 70 tons per hectare yield should be reached even in good years, in order to yield the average 60 tons per hectare in the long run. In this case yield losses from production technological mistakes must not be arisen. Inputs and professional expertise should be used in a maximum way in order to reach yields ensuring profitable production. Investment subsidies may ensure safer return. The return of a superintensive orchard from totally own sources may be risky under the domestic marketing conditions and selling prices, it is strongly uncertain.

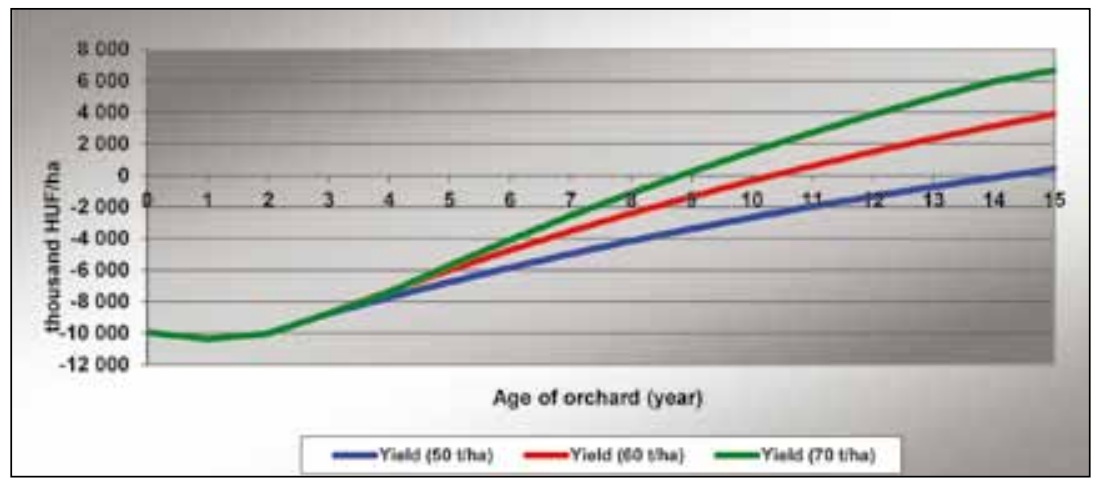

Figure 2: The Tendency of NPV in Superintensive Orchard during the Whole Lifetime in Case of Reaching Different Yield Levels in the Mature State. Source: own calculation

Data in Figure 2 reflect that in orchards of such a huge capital requirement even an average yield of 70 tons per hectare ensures returning only in the $9^{\text {th }}$ year, in case of a profit to capital ratio of $12.9 \%$ and NPV of 6.7 million HUF. The average 50 tons per hectare yield of the mature years, taking an average price of $60 \mathrm{HUF} / \mathrm{kg}$ for apple for consumption purposes into consideration, hardly ensures the payback, namely: great profit may be realized in the average of the mature years (approximately cash flow of 1.0 to 1.2 million HUF/ha, net profit of 300 to 400 thousand HUF/ha), but it provides profit of hardly higher than bank investment. An investment subsidy of $50 \%$ has a great influence on

\section{References}

Brealey, R. A. - Myers, S. C. - Allen, F. (2006): Corporate Finance. Eight Edition, McGraw-Hill, 84-143. p., 244-272. p.

Apáti F. (2009): The comparative economic analysis of Hungarian and German apple production of good standard. ,International Journal of Horticultural Science" 15 (4): 79-85.

Apáti F. (2012): Gyümölcsültetvények fagy- és jégvédelmének technológiai lehetőségei és gazdasági megfontolásai. Debreceni Egyetem AGTC Kertészettudomány Intézet. Debrecen, 227 p.

Gonda I. (2000): Minőségi almatermesztés. [In: Az almatermesztés nemzetközi és hazai helyzete.] Szerk. Gonda I. Nyíregyháza. Primom, 13-14. p.

Illés M. (2002): A beruházások gazdaságossága. [In: Vezetői gazdaságtan. Szerk.: Illés M. Kossuth Kiadó, 115-162. p.

Papp J. (1999): Az EU-összehasonlításban versenyképes kertészeti ágazatok fejlesztési koncepciójának alapjai. [In.: Versenyképes kertészeti ágazatok fejlesztési koncepciójának alapjai - Stratégiai kutatások a Magyar Tudományos akadémián. ](Szerk.: Papp J.) Agroinform Kiadó. Budapest, 8-14. p.

Z. Kiss L. (2003): A gyümölcstermesztés feltételrendszere. [In.: A gyümölcstermesztés, -tárolás, -értékesítés szervezése és ökonómiája.] (Szerk.: Z. Kiss). Mezőgazda Kiadó. Budapest, 13. p. 